\title{
Demographic Characteristics with Osteoporosis in Post Menopausal Women Referred for Osteoporosis Screening by Dual Energy X Ray Absorptiometry
}

\author{
SHANDANA KHAN ${ }^{1}$, RABIA AKHTAR ${ }^{2}$, TAHIR MALIK ${ }^{3}$, HADIA ABID ${ }^{4}$, UMMARA SIDDIQUE UMER ${ }^{5}$, SANA IQBAL ${ }^{6}$ \\ ${ }^{1}$ Assistant Professor Radiology, North West General Hospital and Research Centre, Peshawar \\ ${ }^{2}$ Consultant Radiologist. Safari Hospital/Begum Akhtar Rukhsana Memorial Trust, Rawalpindi \\ ${ }^{3}$ Consultant Radiologist, Director Radiology Residency Programme, Pakistan Kidney and Liver Institute, Bedian Road, Lahore \\ ${ }^{4}$ Assistant Professor Radiology, Rehman Medical Institute Peshawar \\ ${ }^{5}$ Associate Professor Radiology, Rehman Medical Institute Peshawar \\ ${ }^{6}$ Senior Registrar Radiology, North West General Hospital and Research Centre, Peshawar. \\ Correspondence to Dr. Shandana Khan, Assistant Professor Radiology,
}

\begin{abstract}
Aim: Association of various demographic characteristics with osteoporosis in post menopausal women.

Study design: Descriptive study.

Place and duration of study: Radiology Department North West General Hospital and Research Centre, Peshawar, from 15 $5^{\text {th }}$ August 2013 to $14^{\text {th }}$ August 2014.

Methodology: Post menopausal women referred for osteoporosis screening were scanned for bone mineral density (BMD) of the left hip by Dual-energy X-ray absorptiometry (DEXA) technique. Patients who were using any drugs or had any known disease affecting bone metabolism and patients already diagnosed as osteoporotic were excluded. Mean $\pm S D$ were calculated for numerical data using SPSS version 16. Chi-Square test was applied.

Results: Among the 318 post menopausal women, the mean age was $62.51 \pm 9.15$ and menopausal duration $15.19 \pm 8.27$ years. Mean BMI was $29.2 \pm 6.47 \mathrm{Kg} / \mathrm{m}^{2}$. Parity ranged from 0 to 14 children, with mean of $6 \pm$. Overall observed frequency of osteoporosis was $38.1 \%$. Osteoporosis was significantly associated with older age groups $(p<0.05)$. Majority of patients beyond the age of 70 years $(58.3 \%)$ and with menopausal duration of $\geq 21$ years $(52.8 \%)$ had osteoporosis. Low BMI, defined as $\mathrm{BMl}<18.5 \mathrm{Kg} / \mathrm{m}^{2}$, was associated with lower BMD ( $\left.<<0.01\right)$. No significant association was established between early and late onset menopause and osteoporosis, as well as high parity and osteoporosis in our study.

Conclusion: Increasing age, longer duration of menopause, low BMI, and physical inactivity were significantly associated with the presence of osteoporosis.
\end{abstract}

Keywords: Osteoporosis, Menopause, Bone Mineral Density (BMD), Dual-Energy X ray Absorptiometry (DEXA)

\section{INTRODUCTION}

Osteoporosis is defined as abnormality having features of low bone mass and structural degeneration, promoting the development of brittleness of the bones and increasing the risk of fractures of the bones of pelvis, vertebral column and wrists ${ }^{1,2}$. This disease affects women more than men. In a study in Pakistani women with age 45-70 years, the incidence of osteoporosis and osteopenia was found to be $16 \%$ and $34 \%$ respectively ${ }^{3}$. Risk factors of osteoporosis are multiparity, increased post menopausal years, decreased calcium intake with no physical activity ${ }^{4}$. Many drugs and diseases can also aggravate bone loss and fragility ${ }^{5}$. The diagnosis of osteoporosis depends on the assessment of BMD by DEXA technique ${ }^{6}$. Another definition of osteoporosis by WHO is BMD T-score $<-2.5$ below the average value for premenopausal women and osteopenia has T-score between-1.0 and $-2.5^{7}$.

\section{METHODOLOGY}

This was a descriptive study done at The Department of Radiology, North West General Hospital and Research Centre, Peshawar, from $15^{\text {th }}$ August 2013 to $14^{\text {th }}$ August 2014 after approval by the Hospital's Ethical Committee.

Received on 07-03-2021

Accepted on 17-06-2021
Three hundred and eighteen post menopausal women were included in our study. Inclusion criteria of the study were: all post menopausal women referred to the Radiology Department of North West General Hospital and Research Centre, Peshawar for osteoporosis screening. Patients who were using any drugs or had any known disease affecting bone metabolism and patients already diagnosed as osteoporotic were excluded. All the patients were scanned for BMD of the left hip by DEXA technique, using bone densitometer. The results of BMD were expressed as T-score. T-score $<-2.5$ was labeled as osteoporosis and T-score between -1.0 and -2.5 was considered as osteopenia. All the data was recorded and SPSS version 16 was used for data analysis. Chi-Square test was applied to calculate the significance, which was taken as $p \leq 0.05$. Mean $\pm S D$ was calculated for age, age at menopause, duration of menopause, BMI and parity.

\section{RESULTS}

The detail of results is given in tables 1,2

Table 1: Descriptive Statistics
\begin{tabular}{|l|l|l|l|l|l|}
\hline & N & Mini & Max. & Mean & SD \\
\hline Age $($ Yrs $)$ & 318 & 40 & 99 & 62.5 & 9.146 \\
\hline Duration of menopause & 318 & 1 & 51 & 15.2 & 8.253 \\
\hline Age at menopause & 318 & 35 & 57 & 47.3 & 3.430 \\
\hline BMI $\left(\mathrm{Kg} / \mathrm{m}^{2}\right)$ & 318 & 15.5 & 53.5 & 29.2 & 6.471 \\
\hline Parity & 318 & 0 & 14 & 6.1 & 3.118 \\
\hline
\end{tabular}


Table 2: Assessment of risk factors

\begin{tabular}{|c|c|c|c|c|c|}
\hline \multicolumn{6}{|c|}{ Demographic Variable } \\
\hline \multirow{2}{*}{ Age (yrs) } & \multicolumn{3}{|c|}{ DEXA Findings } & \multirow{2}{*}{ Total } & \multirow{2}{*}{ P. Value } \\
\hline & Osteoporosis & Osteopenia & Normal & & \\
\hline$<40-50$ & $14(31.8 \%)$ & $18(40.9 \%)$ & $12(27.3 \%)$ & $44(100 \%)$ & \multirow{5}{*}{0.024} \\
\hline $51-60$ & $36(33 \%)$ & $50(45.9 \%)$ & $23(21.1 \%)$ & $109(100 \%)$ & \\
\hline $61-70$ & $43(36.8 \%)$ & $59(50.4 \%)$ & $15(12.8 \%)$ & $117(100 \%)$ & \\
\hline $71-80$ & $22(55 \%)$ & $15(37.5 \%)$ & $3(7.5 \%)$ & $40(100 \%)$ & \\
\hline $81-100$ & $6(75 \%)$ & $1(12.5 \%)$ & $1(12.5 \%)$ & $8(100 \%)$ & \\
\hline \multicolumn{6}{|c|}{ Duration of menopause (yrs) } \\
\hline $1-20$ & $83(33.74 \%)$ & $115(46.75 \%)$ & $48(19.5 \%)$ & $246(100 \%)$ & \multirow{3}{*}{0.025} \\
\hline $21-40$ & $37(52.11 \%)$ & $28(39.44 \%)$ & $6(8.45 \%)$ & $71(100 \%)$ & \\
\hline$>40$ & $1(100 \%)$ & $0(0 \%)$ & $0(0 \%)$ & $1(100 \%)$ & \\
\hline \multicolumn{6}{|l|}{ Age at menopause (yrs) } \\
\hline$\leq 46$ & $37(33.6 \%)$ & $53(48.18 \%)$ & $20(18.18 \%)$ & $110(100 \%)$ & \multirow{3}{*}{0.704} \\
\hline $47-54$ & $82(41 \%)$ & $88(43.14 \%)$ & $34(16.67 \%)$ & $204(100 \%)$ & \\
\hline$\geq 55$ & $2(50 \%)$ & $2(50 \%)$ & $0(0 \%)$ & $4(100 \%)$ & \\
\hline \multicolumn{6}{|l|}{ BMI $\left(\mathrm{Kg} / \mathrm{m}^{2}\right)$} \\
\hline Weight $<18.5$ & $7(63.6 \%)$ & $2(18.2 \%)$ & $2(18.2 \%)$ & $11(100 \%)$ & \multirow{5}{*}{0.000} \\
\hline Normal 18.5-24.9 & $46(55.4 \%)$ & $29(34.9 \%)$ & $8(9.6 \%)$ & $83(100 \%)$ & \\
\hline Weight 25-29.9 & $39(42.9 \%)$ & $38(41.8 \%)$ & $14(15.4 \%)$ & $91(100 \%)$ & \\
\hline Obese $\geq 30$ & $29(21.8 \%)$ & $74(55.6 \%)$ & $30(22.6 \%)$ & $133(100 \%)$ & \\
\hline TOTAL & $121(38.1 \%)$ & $143(45 \%)$ & $54(17 \%)$ & $318(100 \%)$ & \\
\hline \multicolumn{6}{|l|}{ Parity } \\
\hline Nullipara & $1(7 \%)$ & $6(40 \%)$ & $8(53 \%)$ & $15(100 \%)$ & \multirow{4}{*}{0.200} \\
\hline Primipara (1 child) & $22(40 \%)$ & $25(45 \%)$ & $8(15 \%)$ & $55(100 \%)$ & \\
\hline Multipara (2-4 child) & $37(47 \%)$ & $28(35 \%)$ & $14(18 \%)$ & $79(100 \%)$ & \\
\hline Grand multipara ( $\geq 5$ child) & $61(36 \%)$ & $84(50 \%)$ & $24(14 \%)$ & $169(100 \%)$ & \\
\hline \multicolumn{6}{|l|}{ Physical Activity } \\
\hline Yes & $35(28 \%)$ & $66(52.8 \%)$ & $24(19.2 \%)$ & $125(100 \%)$ & \multirow{2}{*}{0.012} \\
\hline No & $86(44.6 \%)$ & $77(39.9 \%)$ & $30(15.5 \%)$ & $193(100 \%)$ & \\
\hline
\end{tabular}

\section{DISCUSSION}

Our study demonstrated an increased incidence of osteoporosis with increasing age $(P=0.024)$. $75 \%$ of patients above 80 years of age, and $55 \%$ between 71 and 80 years of age were osteoporotic. Ralston $\mathrm{SH}$ et $\mathrm{al}^{8}$ have concluded in their study that the most important risk factors for osteoporosis are increasing age and female gender. Other studies conducted by Liu $\mathrm{H}$ et $\mathrm{al}^{9}$ and Liu $\mathrm{M}$ et $\mathrm{al}^{10}$ have found increasing age as high risk factor for osteoporosis in men.

Significant association was found between duration of menopause and osteoporosis, $52.78 \%$ patients with duration of menopause $>20$ years being osteoporotic. A comparative study by Keramat $A$ et $\mathrm{al}^{11}$ showed that duration of menopause $>5$ years was one of the major risk factors to osteoporosis which was observed in both the populations. Akhlaque $U$ et al $^{12}$ conducted a study which revealed significantly higher number of post-menopausal women having osteoporosis than premenopausal women.

In our study, the number of osteoporotic women with early or late onset menopause was not statistically significant. Qiu C et $\mathrm{al}^{13}$ however showed significantly higher osteoporosis risk in patients with earlier menopause i.e. $\leq 46$ yrs. Zahoor $S$ and Ayub $U$ have concluded that early menopause was associated with osteoporosis. ${ }^{4}$ Another study by Van Der Voort DJ et al ${ }^{14}$ suggested an increased risk of osteoporotic fractures at older age with early menopause. A study by Keramat $A$ et $\mathrm{al}^{11}$ showed that menopausal age before 45 years was one of the major risk factors to osteoporosis in the Indian and Iranian women.

While assessing the relationship between $\mathrm{BMI}$ and osteoporosis, we found the highest percentage (63.6\%) of osteoporosis in the underweight population. A study by Asomaning $\mathrm{K}$ et $\mathrm{al}^{15}$ signified the increased risk of osteoporosis in women with low $\mathrm{BMI}^{15}$. This is in accordance with our study in which there was a gradual decrease in the percentage of osteoporosis with increasing $\mathrm{BMI}$, the lowest percentage being documented in the obese women. Liu $\mathrm{H}$ et $\mathrm{al}^{9}$ have found low body weight as one of the high risk factors in men. We found the same risk factor in post menopausal women. The presumed mechanism is that the adipose tissue secretes adipokines that produce bone remodeling. The bone also affects glucose homoeostasis and body weight through the actions of bone-derived factors such as osteocalcin and osteopontin. This positive feedback through bone-adipose tissue axis maintains both BMI and BMD. Obesity is also associated with better BMD because of the conversion of androgen to estrogen in the adipose tissue ${ }^{12}$.

Regarding relationship between parity and BMD, our study did not show a significant negative effect of increased parity on BMD in the post menopausal women. This is not in favor of study by Keramat $A$ et al, which showed that parity $>3$ was one of the major risk factors to osteoporosis in both the populations ${ }^{11}$. Physical activity was associated with better BMD in our study. This was consistent with a study conducted by Tonnesen $\mathrm{R}$ et $\mathrm{al}^{16}$ who concluded that the BMD in young healthy adults is associated with physical exercise, independent of sex and s-25[OH]D status.

\section{CONCLUSION}

Increasing age, longer duration of menopause, low BMI, and physical inactivity increase the risk of developing osteoporosis.

Conflict of interest: Nil 


\section{REFERENCES}

1. Haussler B, Gothe H, Gol D, Glaeske G, Pientka L, Felsenberg D. Epidemiology, treatment and cost of osteoporosis in Germany- the Bone Eva study. Osteoporos Int 2006; 18:77-84.

2. Zhai G, Hart DJ, Valdes AM, Kato BS, Richards HB, Hakim A, et al. Natural history and risk factors for bone loss in pst menopausal Caucasian women: a 15 years follow up population based study. Osteoporos Int 2008; 19:1211-7.

3. Sultan A, Khan D A, Mushtaq M, Hassan MU. Frequency of osteoporosis and its associated risk factors in postmenopausal women in clinical practice at Rawalpindi. Pak J Pathol. 2006;17:115-118.

4. Zahoor S, Ayub U. Prevalence of osteoporosis in post menopausal women visiting Police and Services hospital, Peshawar, NEFP. JPMI 2010;24(01): 04-08.

5. Raisz LG. Pathogenesis of osteoporosis: concepts, conflicts and prospects. J Clin Invest 2005; 115(12): 3318-25.

6. Kanis JA. Diagnosis of osteoporosis and assessment of fracture risk. Lancet 2002; 359:1929-36.

7. Havs L, Reventlow S, Junsen HL, Malterud K. Awareness of risk of osteoporosis may cause uncertainty and worry in menopausal women. Scand J Public Health 2005; 33: 203-7.

8. Ralston SH, Fraser J. Diagnosis and management of osteoporosis. Practitioner.2015;259(1788):15-19.

9. Liu H, Paige NM, Goldzweig CL, Wong E, Zhou A, Suttorp MJ et al. Screening for osteoporosis in men: a systematic review for an American College of Physicians guideline. Ann Intern Med. 2008 May 6; 148(9):685-701.
10. Liu M, Zhang Y, Cheng X, Lu Y, Li N, Gong Y et al. The effect of age on the changes in bone mineral density and osteoporosis detection rates in Han Chinese men over the age of 50. Aging Male 2014;17(3):166-73.

11. Keramat A, Patwardhan B, Larijani B, Chopra A, Mithal A, Chakravarty $\mathrm{D}$, et al. The assessment of osteoporosis risk factors in Iranian women compared with Indian women.BMC MusculoskeletDisord. 2008;9:28. [PMC free article][PubMed]

12. Akhlaque U, Ayaz SB, Akhtar N, Ahmad N. Association of bone mineral density and body mass index in a cohort of Pakistanis.: relation to gender, menopause and ethnicity. The Egyptian Rheumatologist http://dx.doi.org/10.1016/j.ejr.2016.05.006.

13. Qiu C, Chen $H$, Wen J, Zhu P, Lin F, Huang B et al. Associations between age at menarche and menopause with cardiovascular disease, diabetes and osteoporosis in Chinese women. J Clin Endocrinol Metab. 2013 April;98(4):1612-21.

14. Van Der Voort DJ, Van Der Weijer PH, Barentsen R. Early menopause: increased fracture risk at older age. Osteoporos Int. 2003;14:525-30. [PubMed]

15. Asomaning K, Bertone-Jhonson ER, Nasca PC, Hooven F, Pekow PS. The association between body mass index and osteoporosis in patients referred for a bone mineral density examination. J Womens Health (Larchmt).2006 Nov;15(9):1028-34.

16. Tønnesen $\mathrm{R}, \bigotimes$ Schwarz $\mathrm{P}$, Hovind $\mathrm{PH}$, andJensen $\mathrm{LT}$. Physical exercise associated with improved BMD independently of sex and vitamin D levels in young adults. Eur J Appl Physiol. 2016; 116: 1297-1304. 